\title{
Furnace Brazing of AA5086 Aluminum Alloy with AISI 316L Stainless Steel by ER4047 and ER4043 Fillers
}

\author{
Adnan N. Abood ${ }^{1}$ and Mohammed S. Mohammed ${ }^{2}$ \\ ${ }^{1}$ Middle Technical University, and ${ }^{2}$ University of Technology, Iraq \\ Adnan_naama_59@yahoo.com
}

\begin{abstract}
In this investigation AA5086-H116 aluminum alloys were furnace brazed with AISI316 stainless steel. Brazing process was done with high purity nitrogen gas atmosphere. ER4047 and ER4043 fillers were used with fillers thickness $80 \mu \mathrm{m}$ approximately. Five holding times were employed $(5,10,15,20$ and 25). The microstructures examination showed two bounding layers. First layer from stainless steel side with Fe-rich phases and second layer from aluminum side with Al-rich phase. Joint strength was mainly depended on thickness of these two layers. EDS results demonstrated high diffusion between fillers and two metals to form different intermetallic compounds and there is a clearly relationship between holding time and filler elements diffusion. XRD indicated existing of $\mathrm{Mg}_{2} \mathrm{Si}$ and $\mathrm{Al}-\mathrm{Fe}-\mathrm{Si}$ phases at joining line and diffusion zone, which gives high strength. When holding time raised more than 20 minutes brittle phases $\left(\mathrm{Fe}_{3} \mathrm{Al}, \mathrm{FeAl}\right.$ and $\mathrm{FeAl}_{3}$ ) would form or growth speedily in joining line and diffusion zone. High hardness and brittle nature of these intermetallic phases will decrease mechanical properties of braziments. Shear results recorded 18MPa for the AA5086-H116 joining with ER4047 for 20 minutes and 16Mpa when joining with ER4043 for 20 minutes also.
\end{abstract}

Keywords: Furnace brazing, Dissimilar brazing, AISI 316, Al-Fe-Si, $\mathrm{Mg}_{2} \mathrm{Si}$.

\section{Introduction}

Structure with unique mechanical property and providing potential to utilize the advantages of different materials can be offers by joining dissimilar metal. High level in weight reducing of structural parts can achieved by aluminum applied for its light weight, also excellent corrosion resistance and high strength could marked with stainless steel. Hybrid structures of stainless steel and aluminum alloy are suggested in automotive, spacecraft, and steamship to enhance the fuel efficiency, increase the fly range and control air pollution by reducing the weight ${ }^{[1]}$.
Therefore, in recent years joining stainless steel and aluminum alloy and together has become a hot research field. It is also a great challenge to join these two materials together because of the nearly zero solid solubility of iron in aluminum, large difference between their melting points and the formation of brittle $\mathrm{Al}-\mathrm{Fe}$ intermetallic compounds at elevated temperatures ${ }^{[2]}$.

Stainless steel and aluminum not possible to be joined successfully with current fusion industrial welding techniques, due to the poor compatibility between the two metals many problems would reveal. During transform to a liquid state, there is practically 
no miscibility between the iron and aluminum, and brittle intermetallic $\mathrm{Fe}_{\mathrm{x}} \mathrm{Al}_{\mathrm{y}}$ phases are formed ${ }^{[3]}$. Nevertheless, new techniques for welding solid or mushy metal, such brazing and friction stir welding have been developed. This type of assembly can facilitate with these methods, but with difficulty in implement. Alexandre Mathieu et al., ${ }^{[4]}$ determined the joint shear strength and analysis the joint microstructure of laser brazing between steel/aluminum assembly with hot filler wire ( $88 \% \mathrm{Al}, 12 \% \mathrm{Si}$ ). Hongtao Zhanga et al. ${ }^{\text {[5] }}$ determined joints strength between aluminum alloy and galvanized steel, also the intermetallic compound in fusion zone region close to joint interface when joining stainless steel alloy with aluminum by MIG weldingbrazing method and $4043 \mathrm{Al}-\mathrm{Si}$ filler. The results showed that thickness of intermetallic compound layer varied depending on the heat input. V. Fedorov, et al. [6], evaluated mechanical properties of joints at elevated temperatures. Additionally, investigated the changes in the microstructure when brazing aluminum alloy AA3003 and AISI 304 austenitic stainless steel plates by induction brazing and using Al-Si10 filler and noncorrosive flux. Brazing stainless steel and aluminum raises certain problems, however. The formation of brittle phase's layer at the steel/seam interface leads to poor mechanical properties. These phases growth is derived from a combination of the composition of the filler and of the anisothermic transfer created during brazing at the steel/seam interface. previous publications, e.g. ${ }^{[7]}$, which deal with these intermetallic phases, shows that, if the layer at the steel/seam interface is less than about $10 \mu \mathrm{m}$ thick, the joint will be mechanically acceptable.

\section{Experimental Work}

In this investigation, aluminum alloys AA5086-H116 and AISI316 stainless steel (Tables 1, 2, 3 and 4), were brazed with two fillers ER4047 and ER4043. The flux used was compatible with AWS A5.31 FB1A.

Table 1. Chemical composition of AISI 316 st.st.

\begin{tabular}{|c|c|c|c|c|c|c|c|c|}
\hline Element & $\% \mathrm{C}$ & $\% \mathrm{Si}$ & $\% \mathrm{Mn}$ & $\% \mathrm{P}$ & $\% \mathrm{Cr}$ & $\% \mathrm{Mo}$ & $\% \mathrm{Ni}$ & $\% \mathrm{Fe}$ \\
\hline $\begin{array}{c}\text { Nominal } \\
\text { Chemical } \\
\text { Composition }\end{array}$ & 0.03 & 0.75 & 2.0 & 0.045 & 18.0 & 3.00 & 14.0 & Bal. \\
\hline AISI 316L & 0.027 & 0.47 & 1.41 & 0.033 & 16.27 & 1.98 & 9.71 & Bal. \\
\hline
\end{tabular}

Table 2. Mechanical properties of AISI316 st.st.

\begin{tabular}{|c|c|c|c|c|c|c|c|c|c|}
\hline Properties & $\%$ & $\%$ & $\%$ & $\%$ & $\begin{array}{c}\% \\
\mathrm{Mi}\end{array}$ & $\begin{array}{c}\% \\
\mathrm{Cr}\end{array}$ & $\begin{array}{c}\% \\
\mathrm{Zn}\end{array}$ & $\begin{array}{c}\% \\
\mathrm{Ti}\end{array}$ & $\begin{array}{c}\% \\
\mathrm{Al}\end{array}$ \\
\hline $\begin{array}{c}\text { Material } \\
\text { Cominal } \\
\text { Chemical } \\
\text { Composition }\end{array}$ & 0.40 & 0.70 & 0.50 & 0.10 & 4.50 & 0.25 & 0.25 & 0.15 & $\mathrm{Bal}$. \\
\hline $\begin{array}{c}\text { AA5086- } \\
\text { H116 }\end{array}$ & 0.35 & 0.50 & 0.40 & 0.06 & 4.30 & 0.18 & 0.14 & 0.08 & $\mathrm{Bal}$. \\
\hline
\end{tabular}

Table 3. Chemical Composition of AA5086-H116.

\begin{tabular}{|c|c|c|c|c|c|c|c|c|c|}
\hline Material & $\% \mathrm{Si}$ & $\% \mathrm{Mn}$ & $\% \mathrm{Fe}$ & $\% \mathrm{Cu}$ & $\% \mathrm{Mg}$ & $\% \mathrm{Cr}$ & $\% \mathrm{Zn}$ & $\% \mathrm{Ti}$ & $\% \mathrm{Al}$ \\
\hline $\begin{array}{c}\text { Nominal } \\
\text { Chemical } \\
\text { Composition }\end{array}$ & 0.40 & 0.70 & 0.50 & 0.10 & 4.50 & 0.25 & 0.25 & 0.15 & Bal. \\
\hline $\begin{array}{c}\text { AA5086- } \\
\text { H116 }\end{array}$ & 0.35 & 0.50 & 0.40 & 0.06 & 4.30 & 0.18 & 0.14 & 0.08 & Bal. \\
\hline
\end{tabular}

Table 4. Mechanical Properties of AA5086-H116.

\begin{tabular}{|c|c|c|c|}
\hline Paterial & $\begin{array}{c}\text { Yield } \\
\text { strength } \\
(\mathrm{MPa})\end{array}$ & $\begin{array}{c}\text { Tensile } \\
\text { strength } \\
(\mathrm{MPa})\end{array}$ & $\begin{array}{c}\% \\
\text { Elongation in } \\
50 \mathrm{~mm}\end{array}$ \\
\hline $\begin{array}{c}\text { Nominal } \\
\text { Mechanical } \\
\text { Properties }\end{array}$ & $195 \mathrm{~min}$. & $275 \mathrm{~min}$. & $10 \mathrm{~min}$. \\
\hline AA5086-H116 & 210 & 305 & 11.5 \\
\hline
\end{tabular}

Aluminum specimen's preparation was done by cutting two types of Al alloys and stainless steel to square shape with $20 \mathrm{~mm}$ dimension and 10mm thickness for AA5068H116 alloy, while stainless steel specimen was in rectangular shape with $17 \mathrm{~mm} \mathrm{X} 20 \mathrm{~mm}$ dimensions and $10 \mathrm{~mm}$ thickness, filler alloy AWS ER4047 used as a brazing alloy.

Brazing flux is in powder form designed for torch brazing aluminum. It is typically used to braze common aluminum such as AA1100, AA3003, and AA6061. It has a working temperature starting from $490^{\circ} \mathrm{C}$. Brazing temperature was $620^{\circ} \mathrm{C}$ for $\mathrm{ER} 4047$ filler and 
$635^{\circ} \mathrm{C}$ for ER4043 filler with holding time of $5,10,15,20$ and 25 minutes with nitrogen gas flow rate of $1.5 \mathrm{~L} / \mathrm{min}$. Killer etch $\left(5 \mathrm{ml} \mathrm{H}_{2} \mathrm{O}\right.$, 1.5ml HCL, 2.5ml $\mathrm{HNO}_{3}, 1 \mathrm{ml} \mathrm{HF}$ ) was used for revealing metallographic structure, Mechanical properties assessed using MicroVickers hardness test (MHV) and double shear test. SEM and EDS examination were carried out supplemented for joining line and diffusion zone (DAZ) analysis. X-Ray diffraction used to investigate the formed phases.

\section{Results and Discussion}

Main problem excepted for austenitic stainless steel is the chromic carbide precipitation $\left(\mathrm{Cr}_{23} \mathrm{C}_{6}\right)$ at grain boundary. However, due to low temperature of selected brazing process $\left(620^{\circ} \mathrm{C}\right.$ and $\left.635^{\circ} \mathrm{C}\right)$, with maximum employing time of 25 minutes, probability of $\mathrm{Cr}_{23} \mathrm{C}_{6}$ formation is limited. Austenitic phase undergoes grain growth, because brazing temperature is greater than $400^{\circ} \mathrm{C}$, which represents starting of recrystallization. AISI 316 stainless steel average grain size was $93 \mu \mathrm{m}$ for as reserved condition.

After 5 minutes holding in brazing temperature, grain size growth to $118 \mu \mathrm{m}$ and $128 \mu \mathrm{m}$ when the holding time rising to 20 minutes and $131 \mu \mathrm{m}$ for 25 minutes. Microstructure of AA5086-H116 alloy consists of AlMg in $\alpha$-Al matrix. These compounds would somewhat disappear after 10 minutes of brazing process due to diffusion of $\mathrm{Mg}$ in Al matrix (Fig. 1).

\subsection{Brazing Joint Microstructure}

Two thin layers can recognize at interface between substrates and braze zone. Dark layer from stainless steel side and light color layer from aluminum side can be noticed. Every layer contains number of phases depending on diffusion of elements between base metals and filler alloy ${ }^{[8]}$.
At least two phases were found in brazing joint. M. ROULIN et al., ${ }^{[9]}$ mentioned presence of the same two layers when brazing 99.5\% commercial pure aluminum with AISI 304L stainless steel by using furnace techniques and Al-12Si filler. First and second layers appeared with starting of brazing. Second layer with dark appearance declined after 5 minutes (holding time) and it is responsible for joint failure while the first layer with light color increasing with rising holding time.

Results showed it is obviously that thickness of these two layers affected joint shear strength. Samples with low joint shear strength were showing highest dark layer thickness while samples with highest value illustrating low dark layer thickness with highest light color layer thickness ${ }^{[9]}$.That is mean thickness of dark layer which responsible joint failure is inversely proportional with holding time until saturation point appears after 20 minutes. After this point, relation between thickness of dark layer and joint shear strength is no more inversely proportional, and thickness of this layer is increased with increasing brazing time. Inverse proportional take places. Tables $5 \& 6$ show Fe-Al layer thickness with different brazing time and its impact on the joint shear strength.

Table 5. Al-Fe layer thickness for AA5086-H116 with ER4047.

\begin{tabular}{|c|c|c|c|}
\hline Brazing Time $($ minute $)$ & 5 & 20 & 25 \\
\hline Layer Thickness $(\mu \mathrm{m})$ & 17 & 8 & 12 \\
\hline Joint Shear Strength $(\mathrm{MPa})$ & 3 & 12.6 & 11 \\
\hline
\end{tabular}

Table 6. Al-Fe layer thickness for AA5086-H116 with ER4043.

\begin{tabular}{|c|c|c|c|}
\hline Brazing Time $($ minute $)$ & 5 & 20 & 25 \\
\hline Layer Thickness $(\mu \mathrm{m})$ & 15 & 10 & 12 \\
\hline Joint Shear Strength $(\mathrm{MPa})$ & 3.2 & 16 & 5 \\
\hline
\end{tabular}

The shear results illustrated that when dark layer thickness which contain $\mathrm{Al}-\mathrm{Fe}$ and $\mathrm{Fe}-\mathrm{Cr}$ phases exceed $10 \mu \mathrm{m}$, mechanical 
properties drop off, and this results agreed with G. Sierra et, when joining of steel to /6016-T4 aluminum alloy was achieved by laser braze welding using a 4047 (Al-12Si) filler wire and a brazing flux [10]. Microstructures of transverse section, joining line and DAZ between AA5086-H116 and 316L st.st are shown in Fig. $2 \& 7$.

Figure 2 shows affected $15 \mu \mathrm{m}$ Al-Fe layer thickness with badly impact on joint shear strength. AlMg can be recognized clearly at low brazing time. $\mathrm{Mg}_{2} \mathrm{Si}$ was detected even with 5 minutes. Brazing with ER4043 at 20 minutes (Fig. 3) presents $10 \mu \mathrm{m}$ Al-Fe layer thickness approximately. This value would not deeply affect joint shear strength. In addition, AlMg cannot be noticed any more due to $\mathrm{Mg}$ diffusion in $\mathrm{Al}$ matrix after 10 minutes, while increasing brazing time to 25 minutes, irregular Al-Fe layer thickness illustrated with average thickness of $12 \mu \mathrm{m}$ (Fig. 4). Increasing thickness, more than $10 \mu \mathrm{m}$ has negative effect on shear strength. In addition, AlMg completely disappears from microstructure. Brazing with ER4047 for 5minutes (Fig. 5) reveled $17 \mu \mathrm{m} \mathrm{Al-}$ $\mathrm{Fe}$ layer thickness. This thickness strongly influences in decreased shear strength. AlMg can be observed with low brazing time. High thickness of Al-Fe-Si layer with low $8 \mu \mathrm{m}$ Al-Fe layer thickness can be evidenced with increasing brazing time to 20 minutes Fig. 6 . High Al-Fe-Si layer thickness strongly influences in level up shear strength. Also, low volume fraction of $\mathrm{AlMg}$ can be registered as a result of dissolution. Irregular $12 \mu \mathrm{m}$ Al-Fe layer thickness penetrated inside Al-Fe-Si layer associated with brazing time of 25 minutes Fig. 7. This will reduce positive effect of Al-Fe-Si layer on shear strength and decrease mechanical properties.

\subsection{Elements Distribution}

EDS test results of the first zone from stainless steel side, showed IMCs like Al-Fe-
$\mathrm{Cr}, \mathrm{Al}-\mathrm{Fe}, \mathrm{Fe}-\mathrm{C}$ as well as $\mathrm{Fe}-\mathrm{O}$. Fe is the main element which gives the dark appearance. Second zone from aluminum alloy side showed different IMCs such Al-Fe-Si, $\mathrm{Mg}_{2} \mathrm{Si}$ and Al-Si.

$\mathrm{Al}-\mathrm{Fe}-\mathrm{Si}$, intermetallic compounds need less growth energy comparing with Al-Fe system, so, these phases formed first in joining line ${ }^{[11]}$. Si restricts $\mathrm{Fe}$ from break up, when energy level rises up, Fe-Al start to nucleate. High energy levels give $\mathrm{Fe}$ atoms the applialty to escape and compounds with aluminum and build up Fe-Al intermetallic which had low energy level and form layer just adjacent to first Al-Fe$\mathrm{Si}$ layer ${ }^{[12]}$. Fe-Al compounds have very fast growing rate when energy is enough to create it.

Therefore, Fe-Al layer starts in growing up and decreasing joint shear strength after 20 minutes. Solidified structures in residual liquid revealed intermediate phases, like Alrich, Fe-rich and Mg-rich phases. Al-rich phases presented large discontinuous matrix running length of joint while Fe-rich phases existing in continuous dark morphology along joining zone from stainless steel side. Mg-rich phases, were detected with a dark shaped embedded in Al matrix (Fig. 8 - 10). AA5086H116 brazing with filler ER4043 and 20 minutes was demonstrated $\alpha$-AlFeSi, $\beta$-AlFeSi and $\mathrm{Mg}_{2} \mathrm{Si}$ phases that go well with $\mathrm{S}$. Belmares and A.A. Zaldivar ${ }^{[13]}$. AA5086 alloy is very complicated to braze. Difficult is attained to magnesium rapid diffusion to surface during brazing cycle. Magnesium negatively influences process of oxide removal by flux. It generally accepted in brazing that $\mathrm{Mg}$ levels only up to $0.3 \%$ can be safely braze without any extra preparation and with brazing flux ${ }^{[11]}$. Solid-state diffusion of $\mathrm{Mg}$ in brazing is time-temperature dependent and becomes rapid above $425^{\circ} \mathrm{C}$. When magnesium diffuses to surface during brazing, a chemical reaction takes place with flux resulting in formation of $\mathrm{KMgF}_{3}$. 


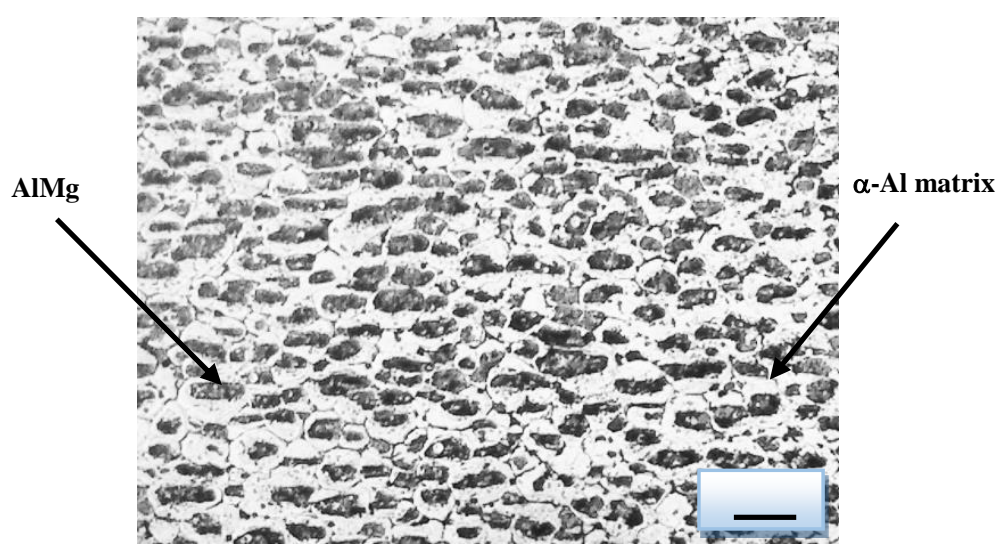

Fig. 1. AA5086-H116 Microstructures before brazing.

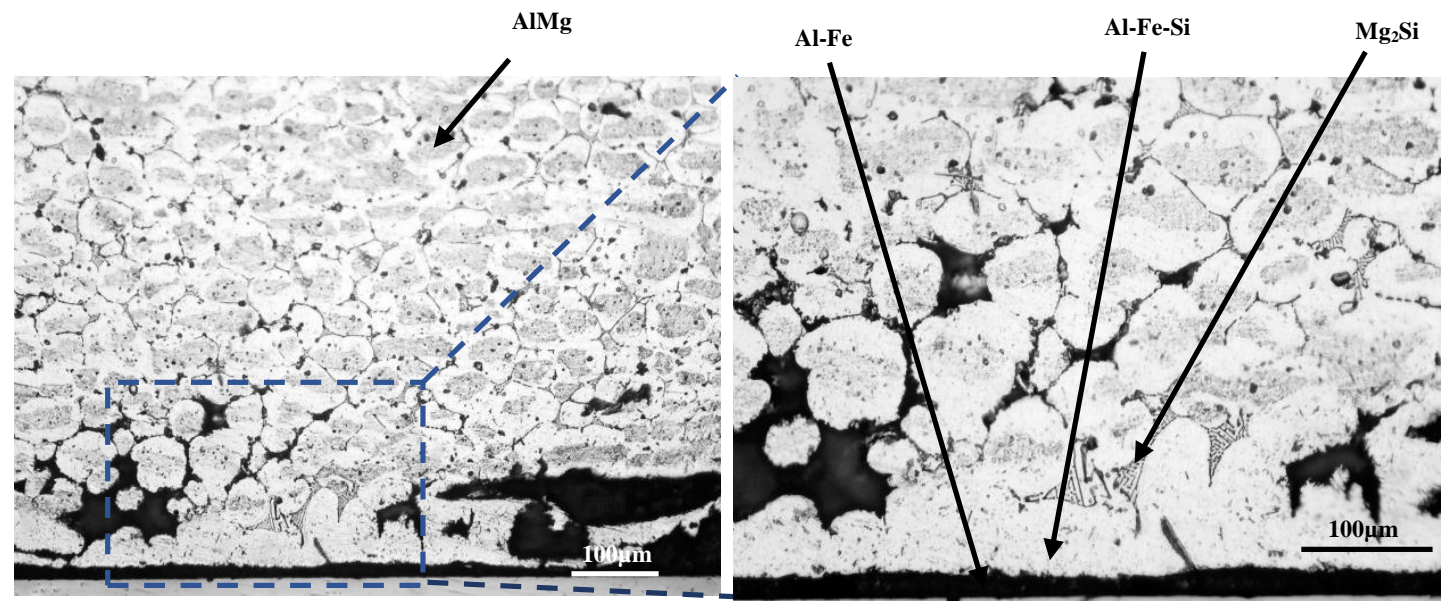

Fig. 2. 5086-H116 brazing joint with ER4043 (5 minutes).

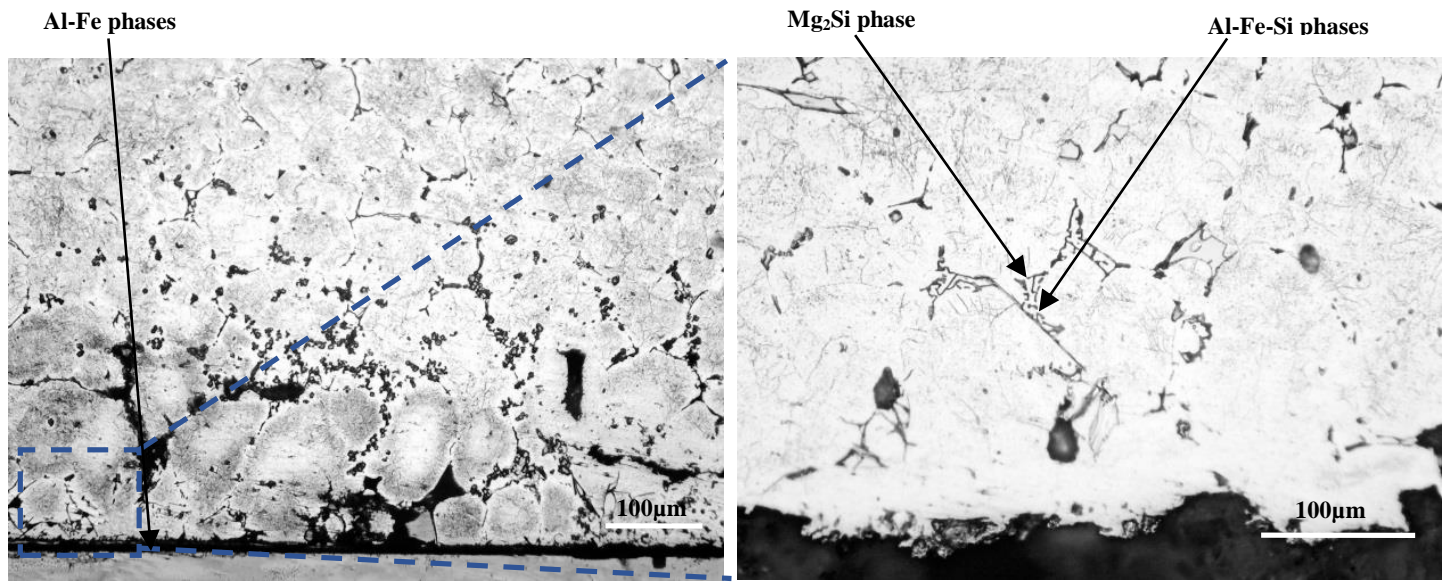

Fig. 3. 5086-H116 brazing joint with ER4043 (20 minutes). 


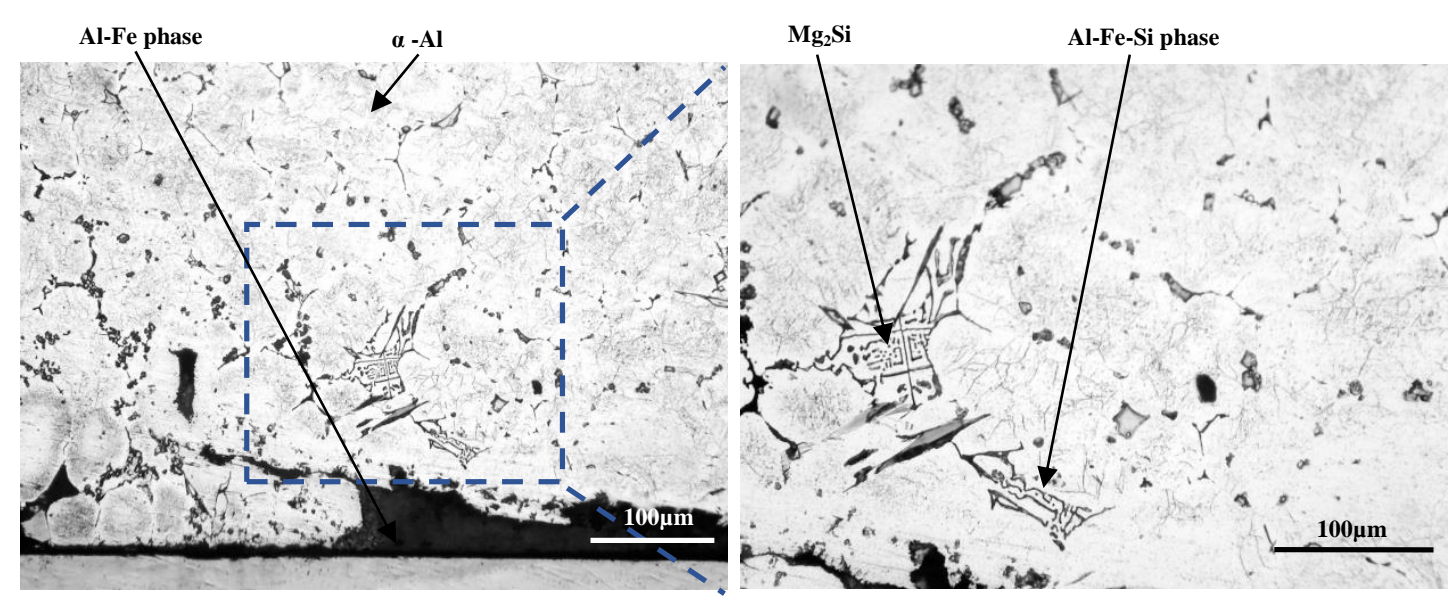

Fig. 4. 5086-H116 brazing joint with ER4043 (25 minutes).

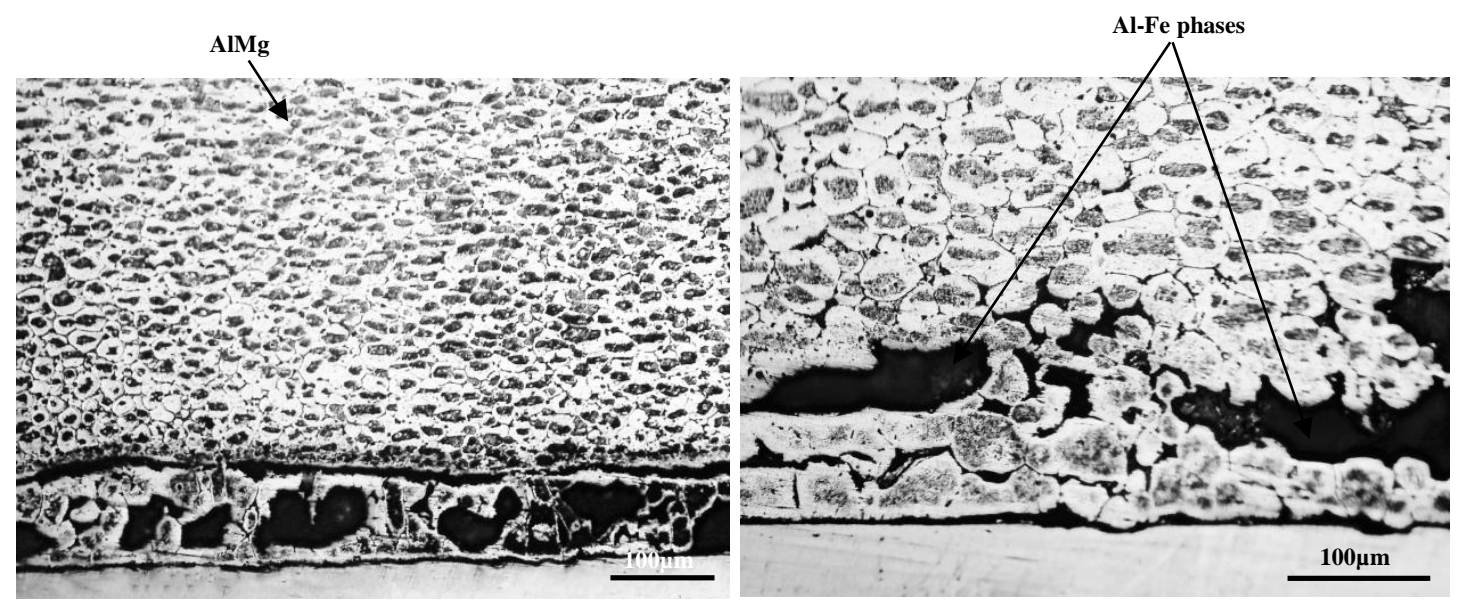

Fig. 5. 5086-H116 brazing joint with ER4047 (5 minutes).

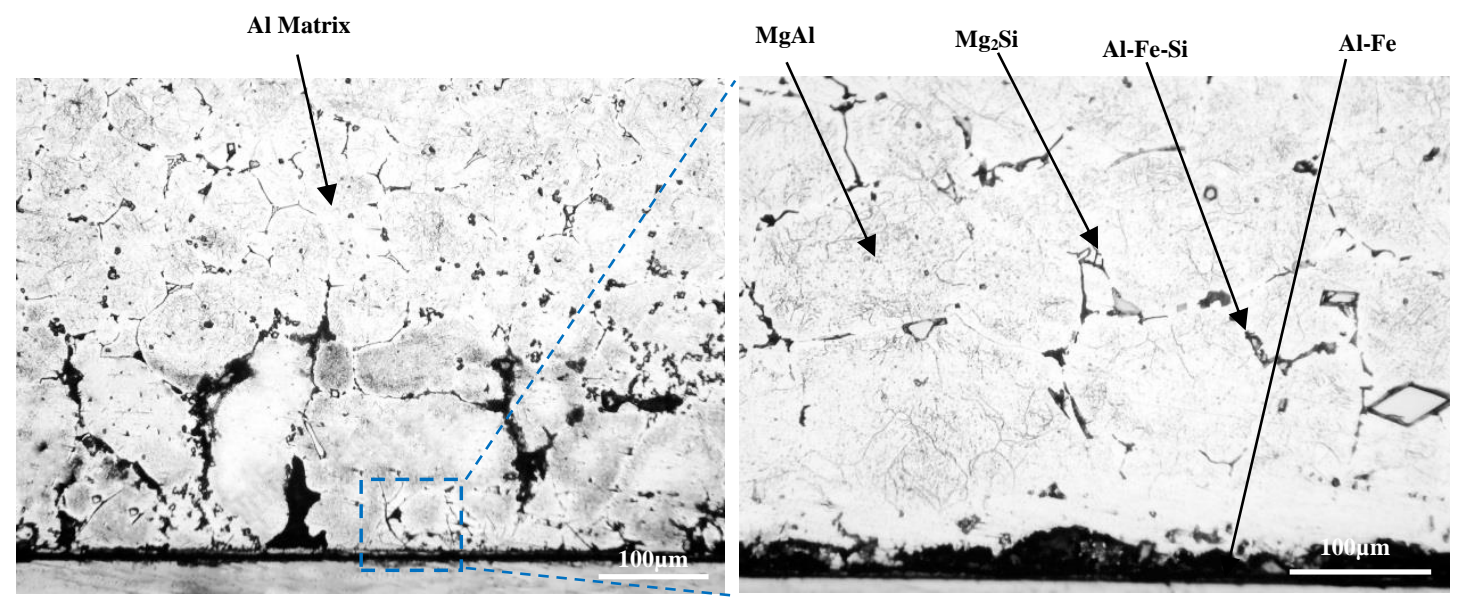

Fig. 6. 5086-H116 brazing joint with ER4047 (20 minutes). 


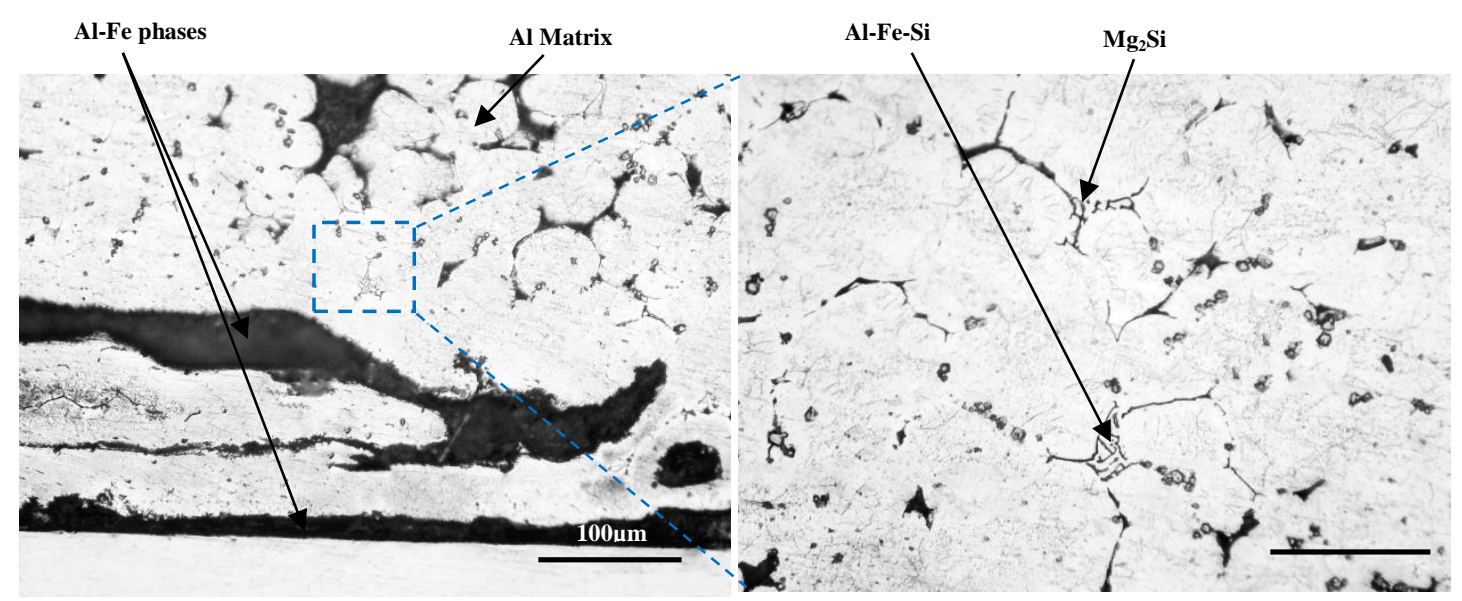

Fig. 7. 5086-H116 brazing joint with ER4047 (25 minutes).

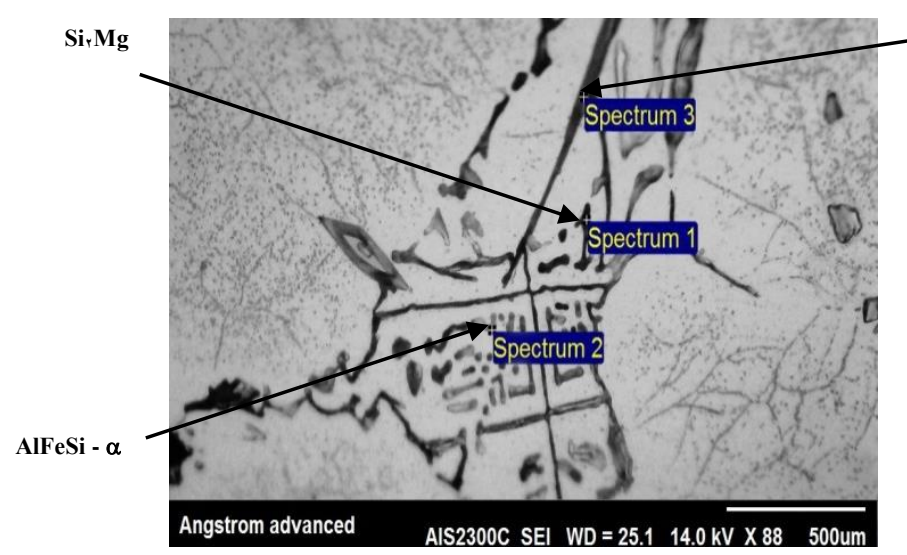

AlFeSi - $\beta$

Fig. 8. 5086-H116 EDS results with ER4043 with 20 min holding time.

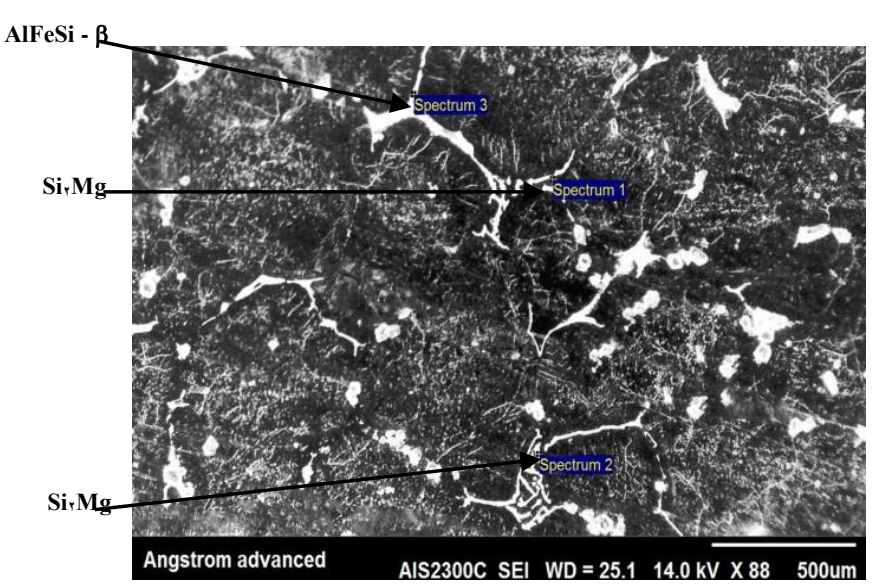

Fig. 9. 5086-H116 EDS results with ER4043 with 25 min holding time. 


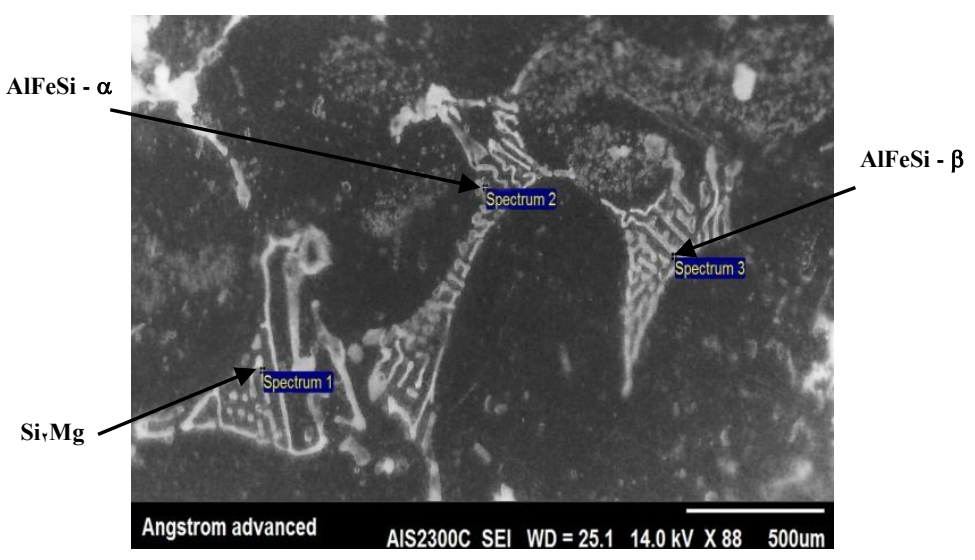

Fig. 10. 5086-H116 EDS results with ER4043 with 5 min holding time.

Rapid diffusion of magnesium to surface is resulting in formation of spinel oxides $\left(\mathrm{Al}_{2} \mathrm{MgO}_{4}\right)$ and magnesium oxide $(\mathrm{MgO})$. Low solubility of these oxides in flux caused a chemical reaction produced potassium magnesium fluorides $\left(\mathrm{KMgF}_{3}, \mathrm{~K}_{2} \mathrm{MgF}_{4}\right)$ and magnesium fluoride $\left(\mathrm{MgF}_{2}\right)$. These compounds change flux composition and rise up its melting temperature more than filler melting temperature, that means when filler melting, there is no oxide removing from the surface done by flux and no wetting and by result no brazing. Magnesium is an extremely rapid reactive element and therefore even a small amount of oxygen in furnace will cause its oxidation. In furnace brazing, oxygen concertation, below brazing temperature is relatively high. Thus, oxidation and formation of magnesium oxides seem to be inevitable. For this reason, to archived successful brazing joint by furnace, thinking must focuses on neutralizing or inhibiting the formation of $\mathrm{Mg}$ oxides and poisoning potassium magnesium fluoride compounds mentioned earlier.

In this investigation low melting temperature flux designed for other aluminum alloys brazing was employed to solve main brazing problem of AA5086 .However, melting range of this flux is below traditional furnace fluxes by $90^{\circ} \mathrm{C}$. This range will overcome problems of flux melting temperature rise up. Another problem is the period between fluxes melting and removing oxide layer from aluminum and stainless steel, as well as, wetting. Furnace flux must be melting and cleaning up brazing surfaces and evaporated just before filler melting starting, usually gap between two processes not more than 10 minutes to avoid regeneration of oxide layer. Time gab of used flux was more than (10) minutes. To avoid oxide layer regeneration, tightly closed brazing retort installing inside brazing furnace and high purity $\mathrm{N}_{2}$ gas continually pumping to neutralize or inhibit the formation of oxide layer after cleaning process. $\mathrm{Mg}_{2} \mathrm{Si}$ was formed in joint and DAZ attributable to presence of $\mathrm{Si}$ from fillers $(5-7 \% \mathrm{Si}$ for ER4043 and 11-13\% $\mathrm{Si}$ for ER4047) and existing of $\mathrm{Mg}$ from base metal. $\mathrm{Mg}_{2} \mathrm{Si}$ phase nucleates at $600^{\circ} \mathrm{C}$. Furnace brazing of AA5086-H116 to stainless steel occurred at $620^{\circ} \mathrm{C}$ or $635^{\circ} \mathrm{C}$ depending on filler type, so diffused $\mathrm{Si}$ from fillers can easily react with $\mathrm{Mg}$ from aluminum to form $\mathrm{Mg}_{2} \mathrm{Si}$ phase ${ }^{[14]}$.

\subsection{XRD Characterization of Microstructure}

XRD analyses of two surfaces of aluminum and stainless steels have revealed the followings: 
(1) Aluminum sides with both fillers detect formation of $\mathrm{Mg}_{2} \mathrm{Si}$ phase.

(2) Intermetallic compounds at joining line from stainless steel side brazed with ER4047 and ER4043 fillers alloy are showing phases of $\mathrm{Fe}-\mathrm{Al}$, $\mathrm{Fe}-\mathrm{Cr}$, and $\mathrm{Fe}-\mathrm{Al}-\mathrm{O}$ without evidences of Si diffusion.

It can be pointed out, also, that Al-Fe-Si phases configured alongside substrate in all joints from aluminum side. While Al-Si phases are distributed at joining line as a residual filler phase. Al-Fe-Si and $\mathrm{Mg}_{2} \mathrm{Si}$ phases are bonding phases, and these phases commanded joint shear strength. XRD analysis showed many phases on both sides (aluminum and stainless steel) along joining line, examination was executed carefully to identify and compare phases constituent patterns with data from the International Centre for Diffraction Data (ICDD) (Tables $7 \& 8$ ).

Table 7. XRD for AA5086-H116 with AISI 316 st.st Brazed by ER4047.

\begin{tabular}{|c|c|c|}
\hline \multicolumn{2}{|c|}{ Brazing time } & Phases \\
\hline \multirow{3}{*}{$\begin{array}{l}\text { Aluminum } \\
\text { side }\end{array}$} & $5 \mathrm{~min}$. & $\begin{array}{c}\mathrm{Mg} \mathrm{g}_{2} \mathrm{Si}-\mathrm{Al}_{8} \mathrm{Fe}_{2} \mathrm{Si}-\mathrm{Al}_{77.69} \mathrm{Fe}_{25.46} \mathrm{Si}_{19.85-} \\
\mathrm{Al}_{3.21} \mathrm{Si}_{0.47}-\mathrm{Al}_{3.96} \mathrm{Si}_{0.04}\end{array}$ \\
\hline & $\begin{array}{c}20 \\
\min .\end{array}$ & $\begin{array}{c}\mathrm{Mg}_{2} \mathrm{Si}-\mathrm{Mg}_{5} \mathrm{Si}_{6}-\mathrm{Al}_{5} \mathrm{FeSi}-\mathrm{Al}_{9} \mathrm{Si}-\mathrm{Al}_{2} \mathrm{FeSi}- \\
\mathrm{Al}_{8} \mathrm{Fe}_{2} \mathrm{Si}-\mathrm{Al}_{77.69} \mathrm{Fe}_{25.46} \mathrm{Si}_{19.85}-\mathrm{Al}_{9} \mathrm{FeSi}_{3}- \\
\mathrm{Al}_{3.21} \mathrm{Si}_{0.47}\end{array}$ \\
\hline & $25 \mathrm{~min}$. & $\mathrm{Mg}_{2} \mathrm{Si}-\mathrm{Mg}_{5} \mathrm{Si}_{6}-\mathrm{Al}_{3} \mathrm{FeSi}-\mathrm{Al}_{77.69} \mathrm{Fe}_{25.46} \mathrm{Si}_{19.85}$ \\
\hline \multirow{3}{*}{$\begin{array}{l}\text { Stainless } \\
\text { steel side }\end{array}$} & $5 \mathrm{~min}$. & $\mathrm{FeAl}_{3}-\mathrm{FeCr}$ \\
\hline & $\begin{array}{l}20 \\
\text { min. }\end{array}$ & $\mathrm{FeNi}-\mathrm{FeAl}-\mathrm{FeCr}-\mathrm{FeAl}_{3}-\mathrm{FeAlO}_{3}$ \\
\hline & $25 \mathrm{~min}$. & $\mathrm{FeAl}_{3}-\mathrm{FeCr}-\mathrm{FeAlO}{ }_{3}$ \\
\hline
\end{tabular}

Table 8. XRD for AA 5086-H116 with AISI 316 st.st Brazed by ER4043.

\begin{tabular}{|c|c|c|}
\hline \multicolumn{2}{|c|}{ Brazing time } & Phases \\
\hline \multirow{3}{*}{$\begin{array}{l}\text { Aluminum } \\
\text { side }\end{array}$} & $5 \mathrm{~min}$. & $\begin{array}{c}\mathrm{Mg}_{2} \mathrm{Si}-\mathrm{Al}_{5} \mathrm{FeSi}-\mathrm{Al}_{9} \mathrm{Si}-\mathrm{Al}_{3.21} \mathrm{Si}_{0.47} \\
-\mathrm{Al}_{3.96} \mathrm{Si}_{0.04}\end{array}$ \\
\hline & $20 \mathrm{~min}$. & $\begin{array}{c}\mathrm{Mg}_{2} \mathrm{Si}-\mathrm{Mg}_{5} \mathrm{Si}_{6}-\mathrm{Al}_{5} \mathrm{FeSi}-\mathrm{Al}_{2} \mathrm{FeSi} \\
-\mathrm{Al}_{8} \mathrm{Fe}_{2} \mathrm{Si}-\mathrm{Al}_{9} \mathrm{Si}-\mathrm{Al}_{4} \mathrm{Si}-\mathrm{Al}_{9} \mathrm{FeSi}_{3} \\
-\mathrm{Al}_{82} \mathrm{Si}_{18}\end{array}$ \\
\hline & $25 \mathrm{~min}$. & $\mathrm{Mg}_{2} \mathrm{Si}-\mathrm{Mg}_{5} \mathrm{Si}_{6}-\mathrm{Al}_{5} \mathrm{FeSi}-\mathrm{Al}_{9} \mathrm{Si}$ \\
\hline \multirow{3}{*}{$\begin{array}{l}\text { Stainless } \\
\text { steel side }\end{array}$} & $5 \mathrm{~min}$. & $\begin{array}{c}\mathrm{FeAl}-\mathrm{Fe}_{1.5} \mathrm{Cr}_{0.2}-\mathrm{Fe} \mathrm{Al}_{3}-\mathrm{FeAlO}_{3}- \\
\mathrm{FeCr}\end{array}$ \\
\hline & $20 \mathrm{~min}$. & $\mathrm{FeCr}-\mathrm{FeAl} l_{3}-\mathrm{FeAlO}_{3}$ \\
\hline & $25 \mathrm{~min}$. & $\mathrm{FeCr}-\mathrm{FeAl} l_{3}-\mathrm{FeAlO}_{3}$ \\
\hline
\end{tabular}

\subsection{Double Shear Test}

Increasing Si percentage has slight effect $(12.5 \%)$ on strength of braziments. Increasing brazing time with ER4047 produced more Si diffusion from filler to joining line and DAZ. This is resulted in high $\mathrm{Al}-\mathrm{Fe}-\mathrm{Si}$ layer thickness and formation of $\mathrm{Mg}_{2} \mathrm{Si}$ phase, this associated with rise of shear strength to a maximum value $18 \mathrm{MPa}$ at 20 minutes brazing time. Phases controlling strength are $\mathrm{Mg}_{2} \mathrm{Si}$ and AI-Fe-Si, Fig. $11 \& 12$ review the shear strength rise up with brazing time increasing for the both fillers.

\subsection{Micro-Hardness of Braziments}

Highest hardness value was recording at interlayer zone. AA5086-H116 brazed with ER4047 filler was recorded $796 \mathrm{HV}$ for 5 minutes. This high value can be ascribed formation of hard (IMCs) phases of Fe-Al compounds like $\mathrm{FeAl}, \mathrm{Fe}_{3} \mathrm{Al}$, and $\mathrm{FeAl}_{3}$. It is reported that $\mathrm{Fe}-\mathrm{Al}$ (IMCs) have a high average hardness range from $330 \mathrm{HV}$ to $1158 \mathrm{HV}{ }^{[15]}$. In addition, it is believed abundant of $\mathrm{Fe}-\mathrm{Al}$ (IMCs), which were recognized evidently in microstructure analysis of brazing joint, responsible high value. Second high value was found at interlayer zone from aluminum side (light layer of joining line) (Fig. 13 - 15) due to formation of $\mathrm{Al}-\mathrm{Fe}-\mathrm{Si}$ and $\mathrm{Mg}_{2} \mathrm{Si}$ in this region. Highest value in this layer was $528 \mathrm{HV}$ of AA5086-H116 alloy with ER4047 and 5 minutes holding time. Hardness of the Al-Fe$\mathrm{Si}$ phases were reported as high hardness values. When these (IMCs) exposure to brazing temperature $\left(620^{\circ} \mathrm{C}\right.$ or $\left.635^{\circ} \mathrm{C}\right)$ for a holding time starting from 5 minutes to 25 minutes, the hardness values reduced to the half or less ${ }^{[16]}$. 


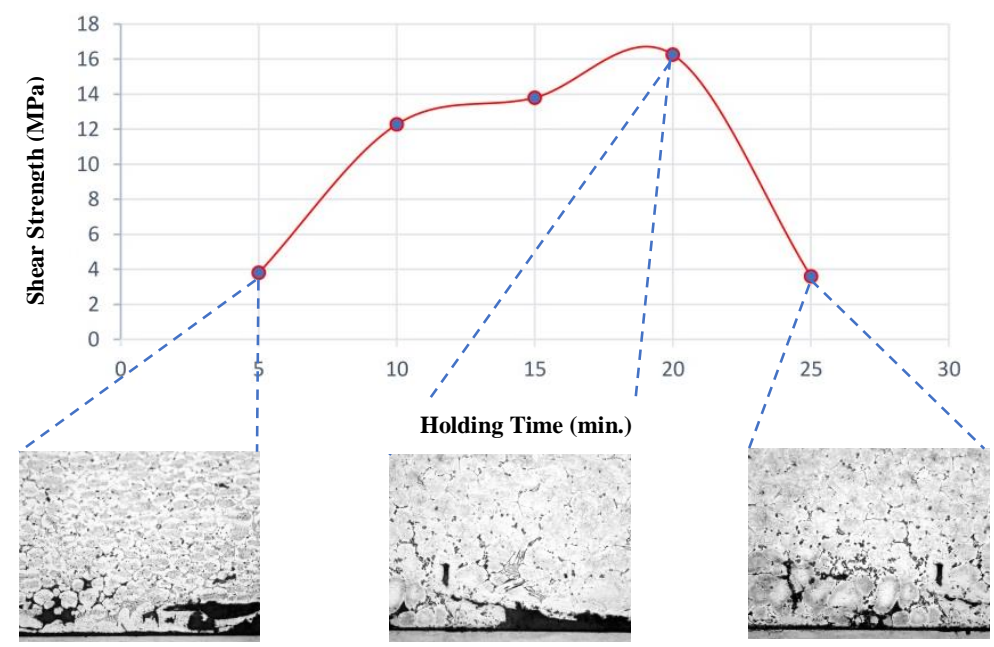

Fig. 11. AA5086-H116 and AISI 316 st.st with ER4043 Shear Strength vs holding time.

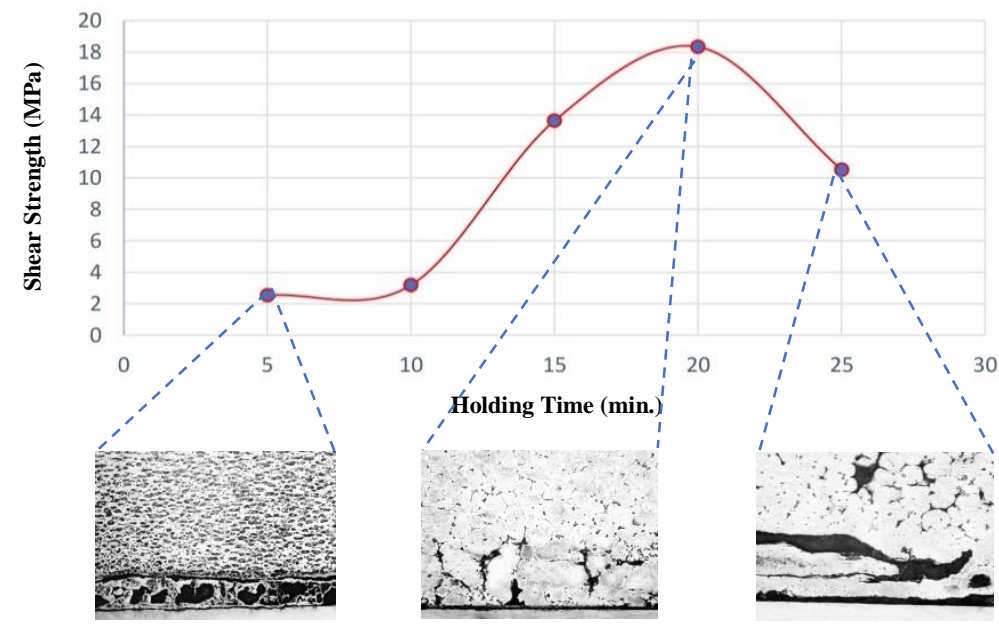

Fig. 12. AA5086-H116 and AISI 316 st.st with ER4047 Shear Strength vs holding time.

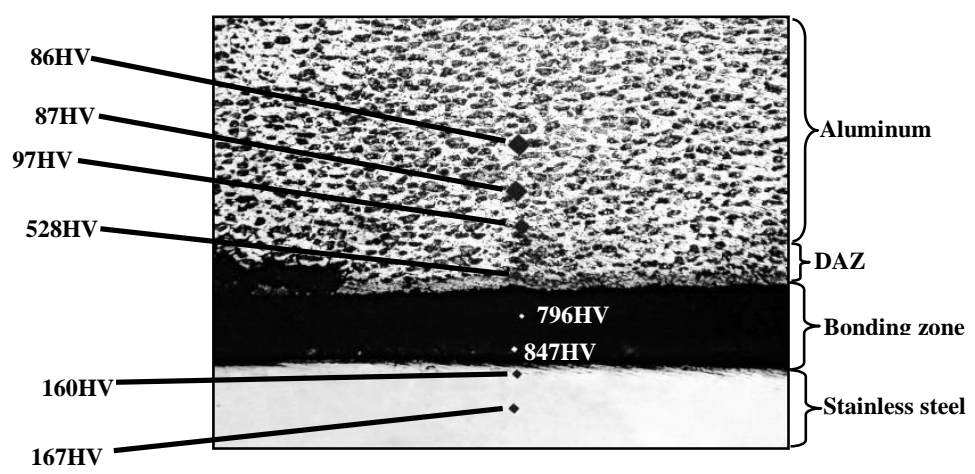

Fig. 13. AA5086-H116 and AISI 316 st.st with ER4047 and 5 min. holding time. 


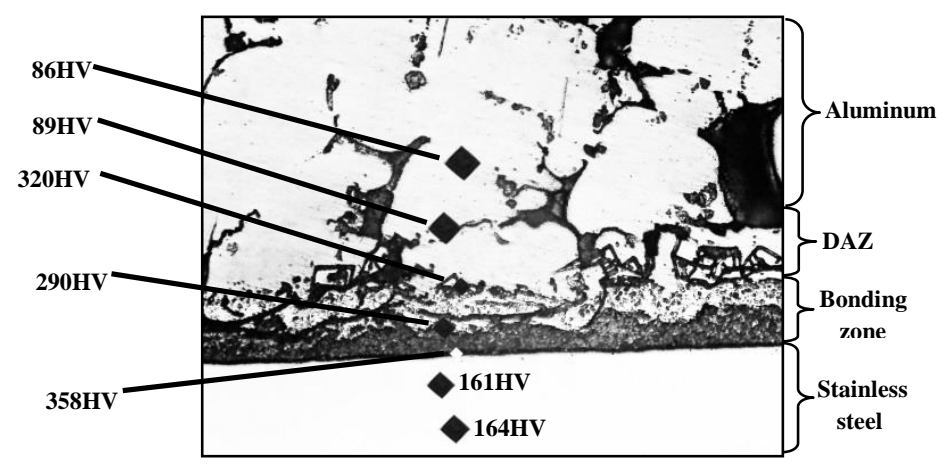

Fig. 14. AA5086-H116 and AISI 316 st.st with ER4047 and 20 min. holding time.

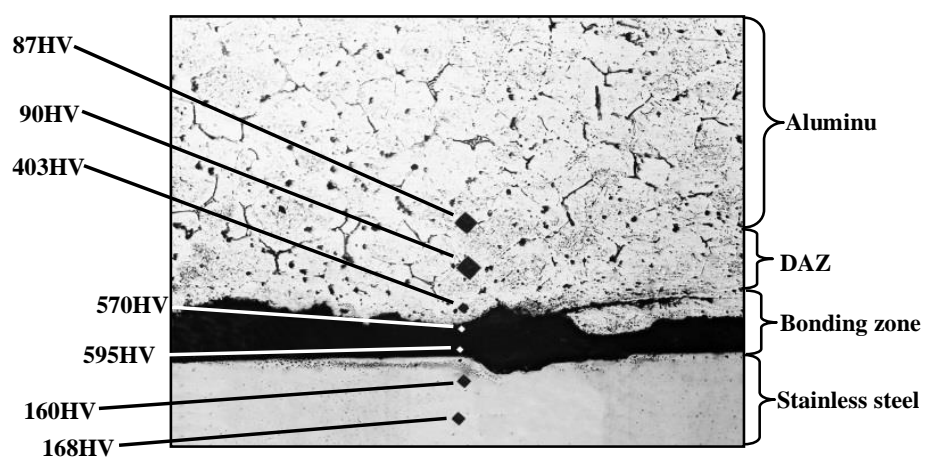

Fig. 15. AA5086-H116 and AISI 316 st.st with ER4047 and 25 min. holding time.

\section{Conclusions}

1. It is possible to braze AA5086 aluminum alloy using aluminum torch flux and ER4047 or ER4043 fillers with $18 \mathrm{MPa}$ and $16 \mathrm{MPa}$ shear strength respectively.

2. Pure nitrogen gas $\left(\mathrm{N}_{2}\right)$ can be used to produce successful joint between aluminum and stainless steel by furnace brazing process.

3. There are two mean layers controlling joint shear strength, first one from stainless steel side with Fe-rich phases (Fe-Al phases and $\mathrm{Fe}-\mathrm{Cr}$ ) and second from aluminum side with Al-rich phases (Al-Fe, Al-Fe-Si, Al-Si) and $\mathrm{Mg}_{2} \mathrm{Si}$ phase.

4. Brazing time is controlling these two layers thickness and controlling shear strength.

5. Fe-rich intermetallic layer thickness is inversely proportional to brazing time until 20 minutes and then growth becomes directly proportional.

6. Al-rich intermetallic and $\mathrm{Mg}_{2} \mathrm{Si}$ layer thickness is directly proportional to brazing time until 20 minute, and then becomes inversely proportional.

7. Increasing thickness of Fe-rich intermetallic layer is inversely proportional with shear strength.

8. $\mathrm{Al}_{\mathrm{x}}-\mathrm{Si}_{\mathrm{y}}-\mathrm{Fe}_{\mathrm{z}}$ and $\mathrm{Mg}_{2} \mathrm{Si}$ phases are controlling shear strength when brazing AA5086-H116 alloy to AISI316 stainless steel.

\section{References}

[1] Zhang, Y., Huang, J., Cheng, Z., Ye, Z., Chi, H., Peng, L. and Chen, S. (2016) "Study on MIG-TIG Double-Sided Arc Welding Brazing of Aluminum and Stainless Steel", Materials Letters 172 (June 2016): 146-148. 
[2] Al- Roubaiy, A. O. (2016)"Characterization of the Nugget Zone Between Aluminum and 304 Stainless Steel Laser Welded", Advances in Natural and Applied Science, 12: 38-48.

[3] Martin, D. C. (1968) "Method of Brazing Aluminum to Stainless Steel for High Stress Fatigue Application", NASA SP-5040 (1968), Library of Congress Catalog Card Number 68-60117.

[4] Alexandre Mathieu, S'ebastien Pontevicci, Jeanclaude Viala, Eugen Cicala, Simone Matte and Dominique Grevey, (2006) " Laser Brazing of a Steel/Aluminium Assembly with Hot Filler Wire (88\% $\mathrm{Al}, 12 \% \mathrm{Si}$ ) ,Materials Science and Engineering, $\mathbf{A}$ 435-436:19-28.

[5] Zhanga, H. and Liua, J. (2011)"Microstructure Characteristics and Mechanical Property of Aluminum Alloy/Stainless Steel Lap Joints Fabricated by MIG Welding-Brazing Process", Materials Science and Engineering, A 528: 6179-6185.

[6] Fedorov, V., Weis, S. and Wagner, G. (2016) "Mechanical and Microstructural Behavior of Brazed Aluminum / Stainless Steel Mixed Joints", Materials Science and Engineering, 118: 1-5.

[7] Song, J.L., Lin, S.B., Yang, C.L., Ma, G.C. and Liu, H. (2009) "Spreading Behavior and Microstructure Characteristics of Dissimilar Metals TIG WeldingBrazing of Aluminum Alloy to Stainless Steel", Materials Science and Engineering, A 509: 3-40.

[8] Sharma, A., Lee, S. H., Ban, H. O., Sik Shin, Y. and Jung, J. (2016) "Effect of various factors on the brazed joint properties in Al brazing technology", Journal of Welding and Joining, 34 (2): 30-35.
[9] Roulin, M., Luster, J. W., Karadeniz, G. and Mortensen, A. (1999) "Strength and structure of furnace brazed joints between aluminum and stainless steel", Welding Journal, (May 1999): 151-155.

[10] Sierra, G., Peyre, P., Beaume, F. D., Stuart, D. and G. Fras, (2008) "Steel to aluminium braze welding by laser process with $\mathrm{Al}-12 \mathrm{Si}$ filler wire", Science and Technology of Welding and Joining, 13(5): 430-437.

[11] Orman, L., Swidersky, H. and Lauzon, D. (2014) "Brazing of aluminium alloys with higher magnesium content using Non-Corrosive Fluxes", Springer series, march 2014, pp: 1-11.

[12] Fan, J., Thomy, C. and Vollertsen, F. (2011) "Effect of Thermal Cycle on the Formation of Intermetallic compounds in Laser Welding of Aluminum-Steel Overlap Joints", Physics Procedia, 12: 134-141.

[13] Belmares-Perales, S. and Zaldivar-Cadena,, A.A. (2010) "Addition of iron for the removal of the $\beta$ $\mathrm{AlFeSi}$ intermetallic by refining of $\alpha$-AlFeSi phase in an $\mathrm{Al}-7.5 \mathrm{Si}-3.6 \mathrm{Cu}$ alloy”, Materials Science and Engineering, B 174: 191-195.

[14] Li, C., Wu, Y.Y., Li, H. and Liu, X.F. (2011) "Morphological evolution and growth mechanism of primary $\mathrm{Mg}_{2} \mathrm{Si}$ phase in $\mathrm{Al}-\mathrm{Mg}_{2} \mathrm{Si}$ alloys", Acta Materialia, 59: 1058-1067.

[15] Fan, J., Thomy, C. and Vollertsen, F. (2011) "Effect of Thermal Cycle on the Formation of Intermetallic compounds in Laser Welding of Aluminum-Steel Overlap Joints", Physics Procedia, 12: 134-141.

[16] Zolotorevsky, V. S. and Belov, N. A. (2007) "Casting Aluminum Alloys", Elsevier Ltd. 


\section{الربط بالمونة باستخدام الفرن لسبيكة الألومنيوم من النوع AA5086-H116 وسبيكة الفولاذ المقاوم للصدأ AISI 316L وباستخدام سبيكة حشو من النوع ER4047 و ER4043 عدنان نعمة عبود' و محمد صبيح محمد 'ب برد 'الجامعة الثقنية المتوسطة، و وجامعة التكنولوجيا، بغداد، العراق Adnan_naama_59@yahoo.com}

الدستخلص. نم في هذا البحث ربط سبيكة الألومنيوم AA5086-H116 مع سبيكة الفولاذ المقاوم للصدأ من النوع AISI 316L بطريقة اللحام بالمونة باستخدام الفرن ومعدن حشو من سبيكة الألومنيوم - سيلكون (ER4047 و ER4043) بسمك .1 ميكروميتر تقرييًا، واستخدام غاز

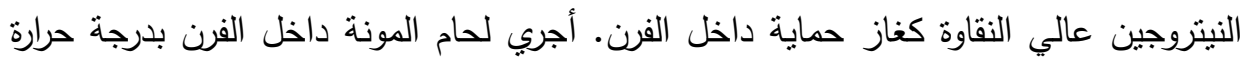

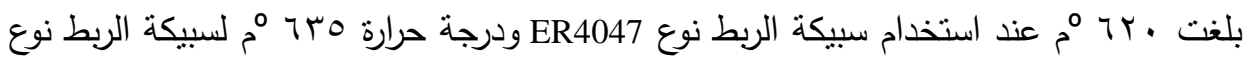

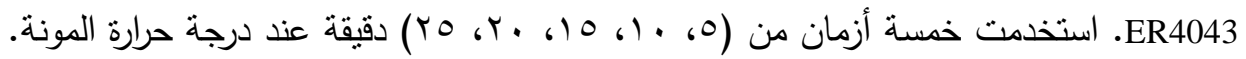
تم اختيار مساعد صهر المستخدم لربط المونة لسبائك الألومنيوم بالمشعل لمعالجة مثاكل لحام سبيكة AA5086-H116. لغرض تحسبن الحماية بواسطة غاز النيتروجين صممت غرفة عزل (retort)

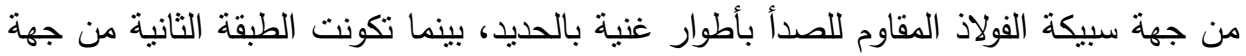

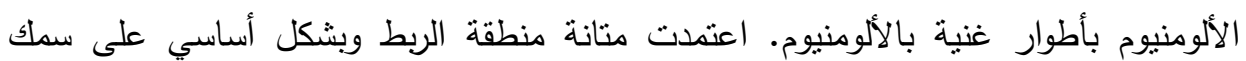

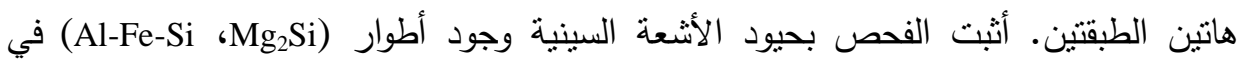
منطقة الربط ومنطقة الانتشار • يعطي تواجد هذه الأطوار منانة عالية. ساعد زيادة زمن اللحام عن عشرين دقيقة على تكون الأطوار الهشة، مثل: ومنطقة الانتشار . تعمل الصلادة العالية والطبيعة الهشة لهذه المركبات بشكل سلبي في تقليل المواصفات الميكانيكية لهنطقة الربط، وقد تؤدي إلى فثلها. تم تنجيل أعلى إجهاد للقص مقداره (MPa18)

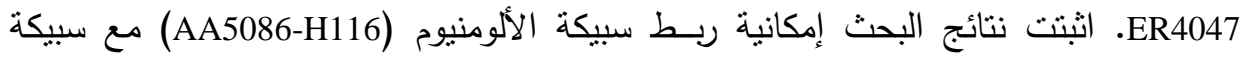

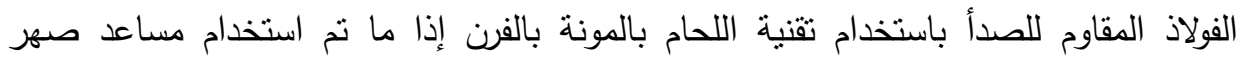
مناسب وسبيكة ربط ملائمة وغاز الحماية المناسب والتكنلوجيا المناسبة. كلمات مفتاحية: اللحام بالفرن بواسطة المونة، الربط بالمونة للمعادن المختلفة، 316 AISI .AA5086-H116, Al-Fe-Si, $\mathrm{Mg}_{2} \mathrm{Si}$ 
